\title{
Removal of Residual Element Tin in the Ferrous Metallurgy Process: A Review
}

\author{
Xiang Zhang ${ }^{1,2} \oplus$, Guojun Ma ${ }^{1,2, *} \mathbb{C}$, Mengke Liu ${ }^{1,2}$ and Zhi Li ${ }^{1,2}$ \\ 1 The State Key Laboratory of Refractories and Metallurgy, Wuhan University of Science and Technology, \\ Wuhan 430081, China \\ 2 Key Laboratory for Ferrous Metallurgy and Resources Utilization of Ministry of Education, \\ Wuhan University of Science and Technology, Wuhan 430081, China \\ * Correspondence: gma@wust.edu.cn; Tel.: +86-27-6886-2810
}

Received: 10 June 2019; Accepted: 24 July 2019; Published: 26 July 2019

\begin{abstract}
With the continuous improvement of the quality of steel for social development, high-quality iron ore resources have been gradually depleted. Meanwhile, the scrap steel reserve and recycling volume are gradually increasing, which will result in the continuous increase of the residual tin content in steel, which seriously restricts the improvement of steel quality and the circulation-utilization of scrap. Therefore, it is necessary to remove as much tin as possible in the ferrous metallurgy process. However, tin in steel cannot be effectively removed in the conventional smelting process. In this paper, the origination, the existing forms, and the content control levels of the residual tin in steel are presented, as well as the current processes of tin removal in the ferrous metallurgy process.
\end{abstract}

Keywords: tin removal; ferrous metallurgy process; residual elements; scrap steel

\section{Introduction}

According to the statistical data reported by world steel association [1], the global crude steel production has been annually increasing, reaching up to 1808.6 million tonnes in 2018. As the requirements of steel production and quality continue to rise, the increasing demand for iron ore has led to the gradual depletion of high-quality iron ore resources and the consequent use of various low-grade iron ore resources containing associated residual elements. Additionally, the total reserve amount and recycling volume of scrap steel have been gradually increasing.

In the steel smelting process, some of the impurity elements can be removed. However, there is still some amount of residual elements that are difficult or impossible to remove using conventional treatment processes, as their affinity for oxygen is less than that for iron-that is, their oxygen potential is lower than iron - and, as a result, these residual elements accumulate in the steel gradually [2].

The problems caused by residual elements in steel have become important issues in the iron and steel industry. In the United States, the development of processes for removing residual elements (e.g., copper and tin) during the steelmaking process has been listed in the 21st century "Steel Industry Technology Roadmap" [3].

Table 1 shows the control standards for residual elements in low-carbon steel plates for compact strip production (CSP) plants, both in China and abroad [4]. It can be seen that the standard for individual or total content of the residual elements $\mathrm{Sn}, \mathrm{Cu}$, and As for low-carbon plain steel plates in China is significantly higher than those in other countries. In particular, the allowable tin content in domestic steel is about one order of magnitude higher than that in other countries. This could be because the amount of tin-bearing iron ore, ferroalloy, and scrap steel used in China is higher than abroad. 
Table 1. Control standard for residual element content in low carbon steel plates for CSP plants in China and abroad, wt $\%$ [4].

\begin{tabular}{ccccc}
\hline Low Carbon Plain Steel Plate & Sn & Cu & As & Cu + 8Sn + 5As \\
\hline American Riverdale & 0.003 & 0.04 & 0.018 & 0.154 \\
Japanese Kawasaki & 0.002 & 0.03 & 0.015 & 0.125 \\
Lianyuan Steel & 0.012 & 0.07 & 0.043 & 0.381 \\
Vf Zhujiang Steel & 0.014 & 0.10 & 0.040 & 0.412 \\
\hline
\end{tabular}

Some current standards, both in China and the United States, are not perfect enough to limit the content of residual elements in different steel grades. For example, in the "GB/T 700-2006 Carbon Structural Steel" standard [5], the As content in steel should be $\leq 0.08 \%$ and the Cu content in Grade A steel should be $\leq 0.35 \%$; meanwhile, a specific restriction of residual tin was not made in the above standard, as well as in the "ASTM A36/A36M-14 Standard Specification for Carbon Structural Steel" [6]. Nonetheless, at present, some Chinese steel enterprises have formulated their own control standards for residual element contents in steel, according to their own raw material characteristics, smelting process, equipment level, and product performance requirements.

Baosteel, Wuhan Iron and Steel, Anshan Iron and Steel, and so on, have strict internal requirements for the content of residual elements in their cold-rolled deep-drawn steel sheets. Baosteel requires $\operatorname{wt}(\mathrm{As}, \mathrm{Sn}) \leq 0.01 \%$ and $w \mathrm{t}(\mathrm{Cu}, \mathrm{Cr}, \mathrm{Ni}) \leq 0.04 \%$; Anshan Iron and Steel requires wt $(\mathrm{Sn}) \leq 0.015 \%$, $\operatorname{wt}(\mathrm{Cu}) \leq 0.08 \%, \mathrm{wt}(\mathrm{Mo}) \leq 0.01 \%$, and $\mathrm{wt}(\mathrm{Ni}) \leq 0.06 \%$; Wuhan Iron and Steel requires deep-drawing plate $\operatorname{wt}(\mathrm{Cu}+\mathrm{Sn}+\mathrm{Mo}+\mathrm{Cr}+\mathrm{Ni}) \leq 0.14 \%$ and tin plate $w t(\mathrm{Cu}+\mathrm{Sn}+\mathrm{Mo}+\mathrm{Cr}+\mathrm{Ni}) \leq 0.12 \%[7]$. For cord steel, Panzhihua Steel requires that the content of residual elements in 72A must meet the standard wt $(\mathrm{Cu}+\mathrm{Cr}+\mathrm{Ni}) \leq 0.05 \%$, wt $(\mathrm{Sn}+\mathrm{As}+\mathrm{Pb}+\mathrm{Bi}+\mathrm{Sb}) \leq 0.04 \%, w t(\mathrm{Sn}) \leq 0.01 \%$, wt $(\mathrm{As}) \leq$ $0.02 \%$, and $w \mathrm{t}(\mathrm{Mo}) \leq 0.02 \%[8]$.

As one of the most common impurity elements in steel, tin is brought into the steel through the furnace burden and ferroalloys used during the smelting process. As it is difficult to oxidize during the steelmaking process, it remains as an impurity in the steel. Although some studies have shown that tin can replace $\mathrm{Pb}$ in order to improve the machinability of steel [9-11], for most steel grades, high tin content can seriously deteriorate the performance characteristics of steel, such as the thermoplasticity [7,12-14], temper brittleness [15-18], and secondary hot working properties [19-21].

With the further development of electric arc furnace (EAF) steelmaking processes and an increase in scrap recycling, the tin content in the steel must be strictly controlled and reducing tin content has a significant effect on developing high quality and high purity steel.

This paper is aimed at introducing the sources of the residual tin in steel during the ferrous metallurgy process. The existing forms of residual tin in steel, including solidification segregation, grain boundary segregation, and surface segregation, are also discussed. Moreover, the merits and defects of tin removal processes in the ferrous metallurgy process are individually analyzed. Finally, the existing problems of tin removal in the ferrous metallurgy process are summarized.

\section{The Sources of Residual Tin in Steel}

The three main sources of residual tin in steel during the ferrous metallurgy process are tin-bearing iron ores, ferroalloys, and scrap steel, respectively.

\subsection{Tin-Bearing Iron Ore}

Tin-bearing iron ore is a complex iron ore resource, which generally has an iron content of 30-55\% and a tin content of $0.2-1.2 \%$ [22]. Iron in tin-bearing iron ore mainly exists in the form of magnetite, and tin mainly exists in the form of cassiterite $\left(\mathrm{SnO}_{2}\right)$ [22]. The cassiterite is mainly embedded in the gangue and magnetite with fine particles, and it is brittle. In addition, some tin exists within the magnetite, in the form of a lattice substitution, which is almost impossible to separate. Therefore, even with the combined beneficiation process of grinding, re-election, magnetic separation, and flotation, it 
is difficult to obtain a good separation of the tin and iron resources, and the tin recovery rate is usually less than $30 \%$. In the ironmaking process, $\mathrm{SnO}_{2}$ in the tin-bearing iron ore can be directly reduced to metallic tin under a strong reducing atmosphere and, thereby, tin enters into the molten iron.

\subsection{Ferroalloys}

Statistically, about $20-45 \mathrm{~kg}$ of ferroalloy is consumed to produce 1 ton of crude steel [23]. Ferroalloy is an important source of tin in the smelting process. In some developed countries, such as the United States and Sweden, the contents of residual elements are already used as one of the standards for quality control of ferromanganese alloy; for instance, the allowable tin contents of low-carbon ferromanganese, mid-carbon ferromanganese, and high-carbon ferromanganese in Sweden are < $0.01 \%,<0.01 \%$, and $<0.02 \%$, respectively [24]. In China, although the contents of residual elements in ferronickel and ferrotungsten are limited, standards have not yet been introduced for ferromanganese and ferrosilicon.

When alloying is applied in the steelmaking process, the residual tin contained in the ferroalloy will enter into the liquid steel, which will result in an increase of tin content. Therefore, it is necessary to strictly control the content of residual elements in ferroalloys.

\subsection{Scrap Steel}

In the ferrous metallurgy process, the largest source of residual tin is scrap steel. At present, a large amount of scrap steel needs to be consumed in both the converter and EAF steelmaking processes. Owing to the advantages of the EAF steelmaking process in terms of economy, energy consumption, environmental friendliness, and resource recovery, EAF steelmaking processes will inevitably become the direction of future development. Scrap steel comprises the vast majority of the iron-bearing charge used in EAF steelmaking, while basic oxygen furnaces can process only up to $10-30 \%$ of scrap steel.

The scrap steel used by iron and steel enterprises is generally divided into three categories [25]: (1) home scrap, from steelmaking and rolling mills, is always used as furnace charge and directly returned to the smelting workshop; (2) process scrap steel, produced by steel processing lines to manufacture automobiles, large-scale instruments and equipment, which has a low content of residual elements; and (3) obsolete scrap steel, mainly from consumer goods, which has the largest proportion (worldwide share $60 \%$ ) and is of mixed origin, from scrapped vehicles, household appliances, steel cans, electrical appliances, and other items, and typically contains high levels of residual elements.

Noro et al. [26] estimated the content level of residual elements in scrap steel in 2020 and indicated that it will be at least 1.2 to 1.5 times of the current content level of residual elements; furthermore, they estimated that the content of residual tin in scrap steel will reach $0.02 \%$ by then.

\section{The Existing Forms of Residual Tin in Steel}

From the iron-tin binary alloy phase diagram (as shown in Figure 1 [27]), it can be found that the main forms of tin in steel are intermetallic compounds, such as FeSn, FeSn, $\mathrm{Fe}_{3} \mathrm{Sn}_{2}$, and $\mathrm{Fe}_{5} \mathrm{Sn}_{3}$. In general, the solid solubility of tin in iron primarily increases with a decrease in temperature. After the solid solubility reaches a maximum, it gradually decreases with a continued decrease in temperature until it reaches a minimum. At room temperature, the solid solubility of tin is close to zero. As tin has a small solidification redistribution coefficient, it is prone to segregation during the solidification of molten steel.

Residual tin can cause solidification segregation during the solidification of the molten steel and can also cause grain boundary segregation in subsequent hot working treatments or solid phase transformations.

(1) Solidification segregation: As tin is a low melting point metal element (with melting point $232{ }^{\circ} \mathrm{C}$ ), its distribution is not uniform during the solidification process. At the same time, the solidification segregation coefficient of the residual tin in iron is 0.5 [28] and, so, tin generally 
does not cause severe macro-segregation under normal solidification conditions. Due to the difference in solubility between solid and liquid phases and selective crystallization, the content of residual tin in the latter dendrites is higher than that in the dendrites formed at the initial stage of crystallization; this will cause a heterogeneous concentration distribution in the internal grain.

(2) Grain boundary segregation: Residual tin may cause grain boundary segregation during the solid phase transformation process or heating process. Compared with solidification segregation, as the residual elements can only diffuse in a short range, the generation of grain boundary segregation generally requires a specific temperature and time, and the position is usually located at the crystal defects; for example, the interfaces between pro-eutectoid ferrite and austenite, and the prior austenite grain boundaries [29-32]. The segregation amount of tin at the grain boundary changes with the cooling rate during the continuous cooling process and the segregation process is dynamic and consistent with non-equilibrium grain boundary segregation [33,34].

(3) Surface segregation: In addition to segregation at the grain boundaries, the residual tin is also enriched at the interface between the steel substrate and the oxide layer. The oxidation potential of tin is lower than that of iron and the melting point of tin is lower than iron, and so the preferential oxidation rate of iron is significantly higher than the diffusion rate of residual tin into the substrate during the high-temperature cooling and secondary heating of the slab $[35,36]$. As a result of selective oxidation, low-melting point tin-concentrating phases inevitably form $[37,38]$.

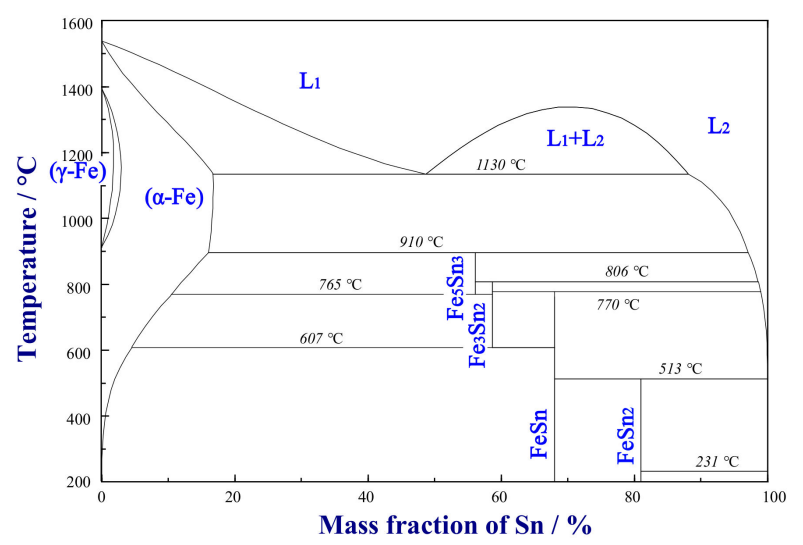

Figure 1. Fe-Sn binary alloy phase diagram [27].

\section{Tin Removal Processes in the Ferrous Metallurgy Process}

At present, the main countermeasures and processes for reducing and controlling tin in steel during the pure steel smelting process mainly include the tin-bearing iron ore roasting treatment process, tin-bearing scrap pre-treatment technologies, ingredient dilution processes, vapor pressure processes, calcium reaction processes, and rare earth treatment processes.

\subsection{Tin-Bearing Iron Ore Roasting Treatment Process}

Currently, the roasting treatment of tin-bearing iron ore means heating the ore under a weakly reducing atmosphere (mainly containing $\mathrm{CO}$ ) and generating a volatile tin-bearing gas, thereby reducing the content of residual tin in the ore. This mainly includes sulfurization-, chlorination-, and reduction-volatilization processes.

\subsubsection{Sulfurization Volatilization Process}

The sulfurization volatilization process is mainly carried out under the conditions of roasting with reducing agents (mainly coke powder and anthracite) and vulcanizing agents, such as pyrite, elemental sulfur and gypsum. By this process, the cassiterite $\left(\mathrm{SnO}_{2}\right)$ in tin-bearing iron ore, which is difficult to 
separate by means of mineral processing, can be converted into the volatile SnS to achieve the purpose of tin-iron separation. The volatilization rate of tin can be as high as $98 \%$ or more in the sulfurization vulcanization process, the operation flow is simple, the raw material adaptability is strong, and the tin-iron separation effect is good. At present, the sulfurization volatilization process is mainly applied to treat tin middling. However, the required roasting temperature is high $\left(1180-1300{ }^{\circ} \mathrm{C}\right)$ and the roasting time is long (120 $\mathrm{min})$, which results in high energy consumption; furthermore, the resulting smoke contains a high content of $\mathrm{SO}_{2}$, which is likely to cause equipment corrosion and environmental pollution. Furthermore, the volatilization rate of tin is not high for processing iron ores with a low tin content.

\subsubsection{Chlorination Volatilization Process}

During the chlorination volatilization process, chlorinating agents (such as $\mathrm{CaCl}_{2}$ and $\mathrm{NaCl}$ ) and reducing agents are added, at an appropriate temperature, to convert tin and other non-ferrous metal elements in the tin-iron ore into chlorides and volatilize them. The melting points of some metal chlorides are shown in Table 2. It can be seen, from Table 2, that the melting and boiling points of the chlorides of different metal elements differ greatly and that the volatile substances are completely different under high-temperature conditions. Based on these different properties, when the complex tin-iron ore is treated by chlorination roasting, the iron chloride is less volatile than the partial non-ferrous metal chlorides and, so, the non-ferrous metal chlorides can be volatilized and removed during the roasting process. Therefore, the chlorination volatilization process can not only effectively realize a high-efficiency separation of tin and iron, but also recover other valuable metal elements. In addition, the calcination temperature is low and the process is easy to operate. A nonferrous metal enterprise of China has carried out semi-industrial experiments to process tin middling by the chlorination volatilization process, and the volatilization rate of tin was as high as about $94 \%$. Nevertheless, the process generates a large amount of chlorine gas, which has strong oxidizing properties and so requires equipment with strong corrosion resistance; furthermore, the emission of chlorine gas can cause harm to the environment. Therefore, the large-scale industrial application of chlorination volatilization processes is restricted.

Table 2. The melting and boiling points of some metal chlorides.

\begin{tabular}{cccccccccc}
\hline Metal Chloride & $\mathbf{S n C l}_{\mathbf{2}}$ & $\mathbf{S n C l}_{\mathbf{4}}$ & $\mathbf{F e C l}_{\mathbf{2}}$ & $\mathbf{F e C l}_{\mathbf{3}}$ & $\mathbf{P b C l}_{\mathbf{2}}$ & $\mathbf{A s C l}_{\mathbf{3}}$ & $\mathbf{Z n C l}_{\mathbf{2}}$ & $\mathbf{C a C l}_{\mathbf{2}}$ & $\mathbf{M g C l}_{\mathbf{2}}$ \\
\hline Melting point $/{ }^{\circ} \mathrm{C}$ & 246 & -33 & 674 & 306 & 501 & -18 & $283-293$ & 782 & 714 \\
Boiling point $/{ }^{\circ} \mathrm{C}$ & 623 & 114 & 1023 & 315 & 951 & 130 & 732 & 1600 & 1412 \\
\hline
\end{tabular}

\subsubsection{Reduction Volatilization Process}

As the affinities to oxygen of tin and iron are different, iron is more easily combined with oxygen, whereas tin is more easily reduced. Both the sulfurization and chlorination volatilization processes require the reduction of $\mathrm{SnO}_{2}$ to $\mathrm{SnO}$ under a weak reducing atmosphere, after which $\mathrm{SnO}$ further reacts with a vulcanizing or chlorinating agent. However, as $\mathrm{SnO}$ has a high vapor pressure at high temperatures, the purpose of separation of tin and iron can be achieved by reducing the volatilization process to avoid some problems, such as equipment corrosion and environmental pollution, caused by the vulcanization and chlorination processes.

Many researchers have studied the treatment of tin-bearing iron ore by reduction volatilization processes, mainly for tin-bearing iron concentrate [39-43]. The reducing agents used are mainly anthracite, coke breeze, lignite, and $\mathrm{CO} / \mathrm{CO}_{2}$ mixed gas. The main volatilization processes include high-wustite pellets, produced by weak reduction calcination, and metallized pellets, produced by direct reduction. The roasting temperature is $1040-250{ }^{\circ} \mathrm{C}$ and the roasting time is $30-180 \mathrm{~min}$. Experimental results have showed that the reduction volatilization treatment of tin-iron can achieve better tin-iron separation effects both in the laboratory and at the semi-industrialized stage. Due to high energy consumption, a large demand for reducing agents, tin sulfide composition fluctuation 
affecting the volatilization effects of tin, difficulty in controlling the system atmosphere, and other factors, the industrialization of reduction volatilization processes is limited.

All of the above tin-bearing iron ore roasting treatment processes have their own merits and defects, and they cannot be effectively industrialized. At present, the mainstream industrial process to remove tin from tin-bearing iron ore is through integrated traditional mineral separation techniques.

\subsection{Tin-Bearing Scrap Steel Pre-Treatment Technology}

Tin-bearing scrap steel is mainly tin-plated sheet steel, its main source being various kinds of packaging containers, such as recovered cans, with the amount of tin being about $0.5-2 \%$. With the wide application of various coating (plating) layer materials, the tin content of scrap steel recovered from household appliances, automobile panels, and bearings is also high. For the pre-treatment technology of tin-bearing scrap, the main processes currently adopted in the industry include alkaline electrolyte electrolysis, alkaline solution leaching, and chlorination.

\subsubsection{Alkaline Electrolysis Process}

The alkaline electrolysis process is a widely used process in the industry. The tin-plated steel sheet is used as an anode, the iron plate is used as a cathode, and an alkaline aqueous solution, such as $\mathrm{NaOH}, \mathrm{Na}_{2} \mathrm{SnO}_{3}$, or $\mathrm{Na}_{2} \mathrm{CO}_{3}$, is used as an electrolyte [44]. When a direct current is applied, the tin in the anode tin-plated steel sheet is dissolved to form $\mathrm{Na}_{2} \mathrm{SnO}_{2}$ and $\mathrm{Na}_{2} \mathrm{SnO}_{3}$. As $\mathrm{SnO}_{2}^{2-}$ and $\mathrm{SnO}_{3}^{2-}$ are unstable, they will be further hydrolyzed to form $\mathrm{HSnO}_{2}^{-}$and $\mathrm{Sn}(\mathrm{OH})_{6}^{2-}$. The actual dissolution reactions occurring at the anode are as follows:

$$
\begin{gathered}
\mathrm{Sn}+3 \mathrm{OH}^{-}=\mathrm{HSnO}_{2}^{-}+\mathrm{H}_{2} \mathrm{O}+2 \mathrm{e}^{-} \\
\mathrm{HSnO}_{2}^{-}+3 \mathrm{OH}^{-}+\mathrm{H}_{2} \mathrm{O}=\mathrm{Sn}(\mathrm{OH})_{6}^{2-}+2 \mathrm{e}^{-}
\end{gathered}
$$

The following reactions occur more easily:

$$
2 \mathrm{HSnO}_{2}^{-}+2 \mathrm{H}_{2} \mathrm{O}=\mathrm{Sn}+\mathrm{Sn}(\mathrm{OH})_{6}^{2-}
$$

Therefore, tin is mainly present in the form of $\mathrm{Sn}(\mathrm{OH})_{6}^{2-}$.

At the cathode, $\mathrm{Sn}(\mathrm{OH})_{6}^{2-}$ mainly accepts electrons, and the tin is reduced as:

$$
\mathrm{Sn}(\mathrm{OH})_{6}^{2-}+4 \mathrm{e}^{-}=\mathrm{Sn}+6 \mathrm{OH}^{-}
$$

The content of tin in the anode mud obtained by the alkaline electrolysis process is generally about $20 \%$, and the total recovery rate of the tin-plated steel sheet scrap can reach $90-95 \%$. The anode mud can be recovered by a reduction process (or another process) to obtain the tin.

\subsubsection{Alkaline Solution Leaching Process}

Alkaline solution leaching processes use a hot sodium hydroxide solution to dissolve the tin-plated steel sheet, in which the tin reacts with the solution to form $\mathrm{Na}_{2} \mathrm{SnO}_{3}$; thereby, the separation between tin and steel can be achieved, and the reaction is:

$$
\mathrm{Sn}+2 \mathrm{NaOH}+\mathrm{H}_{2} \mathrm{O}=\mathrm{Na}_{2} \mathrm{SnO}_{3}+2 \mathrm{H}_{2} .
$$

As the super-voltage of the reaction product hydrogen is large, the reaction is slow; however, the addition of an oxidizing agent (such as $\mathrm{O}_{2}, \mathrm{PbO}, \mathrm{MnO}_{2}, \mathrm{NaNO}_{3}$, and so on) can promote the progress of the reaction:

$$
\mathrm{Sn}+2 \mathrm{NaOH}+\mathrm{O}_{2}=\mathrm{Na}_{2} \mathrm{SnO}_{3}+\mathrm{H}_{2} \mathrm{O}
$$


For the obtained leachate, tin is generally recovered by precipitation or insoluble anodic electrolysis. The precipitating agent used in the precipitation process may be, for example, $\mathrm{CO}_{2}, \mathrm{NaHCO}_{3}, \mathrm{Ca}(\mathrm{OH})_{2}$, $\mathrm{H}_{2} \mathrm{SO}_{4}$, and so on, and the precipitate can be further reduced and smelted to obtain tin. For the insoluble anodic electrolysis process, the tin composition of the anode can reach $99.85 \%$, and the current efficiency and electrical energy consumption are $70 \%$ and $4000 \mathrm{kwh} / \mathrm{t}$ tin, respectively [45].

\subsubsection{Chlorination Process}

$\mathrm{Cl}_{2}$ and tin have a strong affinity. At the same time, $\mathrm{SnCl}_{4}$ has a low boiling point $\left(113^{\circ} \mathrm{C}\right)$ and, so, it has a large vapor pressure at normal temperature; thus, it can be easily separated from iron. The main chemical reaction of the chlorination process is as follows:

$$
\mathrm{Sn}+2 \mathrm{Cl}_{2}=\mathrm{SnCl}_{4}
$$

However, the chlorination process requires that the tin-coated steel sheet scrap does not contain moisture and organic matter (such as paint, paper, and so on); otherwise, the chlorine would react with the iron. From the point of chemical reaction, the principle of chlorination is relatively simple, but the practice is more difficult. This mainly because a chlorination reaction releases a lot of heat, and the subsequent high temperature will cause $\mathrm{SnCl}_{4}$ to boil. When the temperature is higher than $40^{\circ} \mathrm{C}$, it will promote the chlorination of iron. Therefore, it is necessary to continuously discharge excess heat in the chlorination process to make sure the reaction is carried out at a relatively low temperature (generally, $38^{\circ} \mathrm{C}$ ). Furthermore, as the chlorination reaction proceeds, the pressure in the reactor reduces, and the input gas must be continuously pressurized. The $\mathrm{SnCl}_{4}$ obtained by the chlorination process can be treated by a substitution process or an insoluble anodic electrolysis process to obtain metal tin.

\subsection{Ingredient Dilution Process}

The ingredient dilution process is the most common and simple measure adopted by steel enterprises to reduce the concentration of residual elements in steel. The ingredient dilution process dilutes molten steel in the production process by using cold/hot direct reduced iron (DRI) [46], hot briquetted iron (HBI) [47], iron carbide [48], blast furnace molten iron, and other scrap substitutes, in order to achieve the purpose of controlling the cleanliness of the molten steel. For example, the main raw materials of EAF in Baosteel include scrap steel, pig iron, and molten iron. By optimizing the ratio of these main raw materials, the concentrations of residual elements in the molten steel can be effectively controlled [49].

The proportion of substitute scrap steel is generally about $30 \%$ in furnace burden, and the highest addition proportion of pig iron or molten iron can reach up to $70 \%$. In addition to diluting the concentration of residual elements, this can also provide a large amount of sensible heat and latent heat to improve the technical and economic indicators of the EAF process [50]. Some studies have indicated that DRI has an excellent dilution effect on the residual elements in the molten steel. As shown in Figure 2 [50], the total concentration of residual elements in the molten steel linearly decreases with the improvement of the DRI blending amount. After the DRI is added to the charge, the strong "carbon boiling" in the furnace can promote the removal of gases and impurities in the molten steel and play a role in purifying the molten steel.

Although the dilution process can effectively reduce the concentration of residual elements in the molten steel, it requires sufficiently high-quality iron ore and iron source. If scrap containing $0.15 \%$ tin is diluted to $0.01 \%$ or less, it must consume 15 times as much of the clean iron source [51]. Meanwhile, as steel production increases, iron ore resources are gradually depleting. Thereby, if the residual elements in the steel cannot be effectively removed, the residual elements will circularly enrich in the scrap steel, which will result in a part of the scrap steel that cannot be recycled to the furnace. According to statistics, the annual amount of scrap steel which cannot be recycled accounts for about $7 \%$ of the total scrap steel [52]. This has caused the world to accumulate tens of millions of tons of 
"reusable scrap" every year. Therefore, it is necessary to make full use of various types of scrap steel resources and simultaneously develop effective removal technologies for residual elements in the steelmaking process.

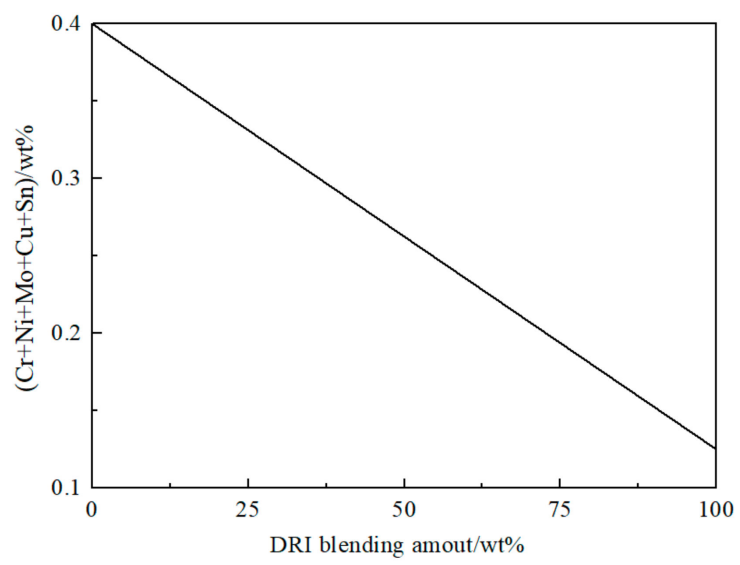

Figure 2. Relationship between direct reduced iron (DRI) blending amount and residual element content in liquid steel [50].

\subsection{Vapor Pressure Process}

The vapor pressure process is a process of separation based on the difference between the vapor pressure of the residual elements and iron in a vacuum state. The saturated vapor pressures of liquid iron and liquid tin at different temperatures are shown in Table 3 [53]. As can be seen from Table 3, the saturated vapor pressure of pure metal Fe is $(2.7-5.8) \times 10^{-2}$ times as many as that of pure metal tin at the same temperature and, so, tin is more likely to volatilize into the gas phase than Fe.

Table 3. Saturated vapor pressures of pure iron and tin at different temperatures, $\mathrm{Pa}$ [53].

\begin{tabular}{cccccccc}
\hline Temperature $\left({ }^{\circ} \mathbf{C}\right)$ & $\mathbf{1 4 0 0}$ & $\mathbf{1 4 5 0}$ & $\mathbf{1 5 0 0}$ & $\mathbf{1 5 5 0}$ & $\mathbf{1 6 0 0}$ & $\mathbf{1 6 5 0}$ & $\mathbf{1 7 0 0}$ \\
\hline $\mathrm{Fe}$ & 0.3327 & 0.7311 & 1.507 & 2.742 & 5.176 & 9.311 & 16.41 \\
$\mathrm{Sn}$ & 12.16 & 22.59 & 40.55 & 70.47 & 118.9 & 194.98 & 311.9 \\
\hline
\end{tabular}

Xiong et al. [53] used a vacuum induction furnace to explore the separation of a tin-iron alloy. The results showed that the distillation time and temperature had a significant effect on the tin removal effect, and that the distillation temperature was more significant. As the distillation time was extended and the temperature increased, the tin removal rate was significantly increased. When the distillation temperature was $1612{ }^{\circ} \mathrm{C}$, the furnace pressure was $10 \mathrm{~Pa}$, and the distillation time was $42.5 \mathrm{~min}$, the tin removal rate in the tin-iron alloy (the initial content of tin was $4.45 \mathrm{wt} \%$ ) was as high as $99.79 \%$. Nevertheless, when the pressure in the furnace was in the range of $0.1-100 \mathrm{~Pa}$, the tin removal ratio did not change significantly. Lipart et al. [54] found that, when the gas pressure in the furnace was less than $10 \mathrm{~Pa}$, the controlling process of the tin removal reaction was mass transfer in the liquid phase. When the gas pressure ranged from 10-100 $\mathrm{Pa}$, the mass transfer between the gas and the liquid phase was the controlling process. Finally, the controlling process turned into the mass transfer in the gas phase with gas pressures greater than $100 \mathrm{~Pa}$. By electromagnetic induction stirring under negative pressure conditions, the tin removal reaction in the high-carbon molten iron conforms to the first-order rate law and is controlled by the gasification reaction and the liquid phase mass transfer with pressures in the range of $1-50 \mathrm{~Pa}[55,56]$.

Several research results have shown that injecting weak oxidant powders (such as $\mathrm{SiO}_{2}$ and $\mathrm{MgO}$ ) through the surface of molten iron at appropriate negative pressures can improve the degree of liquid disturbance, promote the generation of vast fine $\mathrm{CO}$ bubbles, and increase the volatilization interface region, thereby accelerating the tin evaporation rate (as shown in Figure 3 ) $[57,58]$. Blowing gas into 
molten steel has also been studied to improve the tin removal ratio. Sasaki et al. [59] studied the tin removal process with blowing of $\mathrm{NH}_{3}$ under vacuum conditions and pointed out that the highest tin removal rate was about $40 \%$ under the conditions of $1450-1650{ }^{\circ} \mathrm{C}$; furthermore, tin was volatilized (in the form of $\mathrm{SnS}$ ), and the higher the $\mathrm{S}$ content in the melt, the better the degree of tin removal.

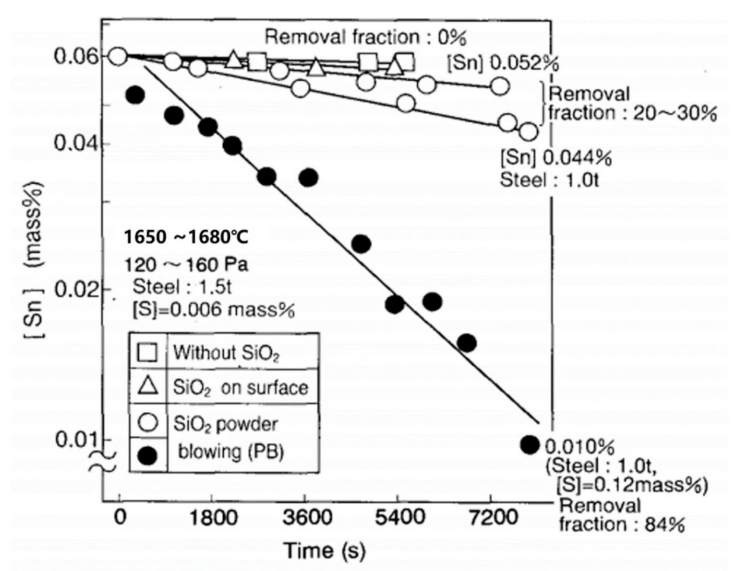

Figure 3. Variation of Sn content in molten iron with time under low pressure [57].

With regard to the effect of other elements in steel on the tin removal ratio, Savov et al. $[55,56]$ and Mastsuo et al. [57] pointed out that the presence of C, Si, and $\mathrm{Cr}$ in the melt could promote tin removal, while the presence of $\mathrm{Ni}$ had an adverse effect.

As the tin removal reaction is endothermic, this will lead to heat loss and is disadvantageous for the processing of the removal reaction. Hence, a plasma heating method was investigated, and the relative results showed that it could compensate for the heat loss of removal reaction and, thereby, improve the tin removal ratio $[58,60]$. In addition, the tin removal ratio was improved with low negative pressure, high $\mathrm{H}_{2}$ content, and high gas flow rate by using a plasma furnace under $\mathrm{Ar}-\mathrm{H}_{2}$ and Ar gases.

Nevertheless, Zaitsev et al. [61] indicated that the efficiency of removing tin by vapor pressure processes is low. At the same time, if the vapor pressure process is used in actual production, the pressure in the furnace should be kept low. This will lead to difficulty in operation, high treatment costs, long operation times, large iron losses, and low production efficiency. Thereby, the vapor pressure process is still at the laboratory-scale research stage.

\subsection{Calcium Reaction Process}

Calcium reaction processes are also called chemical denaturing processes. By adding a mixture of metal calcium, calcium halide, or calcium-containing slag to the molten steel, the residual elements in the molten steel are fixed in the form of a compound, and the residual elements, such as Sn, As, Sb, and so on, can be removed within a certain range. Thereby, the adverse effects of the segregation of residual elements at the grain boundaries on the properties of the steel can be alleviated.

Calcium metal is a high-quality reducing agent for removing residual elements, but its evaporation loss is large, and the solubility of calcium in molten steel is very low and only about $0.025 \% \pm 0.008 \%$. As a consequence, calcium-containing slag, such as $\mathrm{CaC}_{2}$ or $\mathrm{CaF}_{2}$, is usually used instead of calcium metal [62].

Ochifuji et al. [63] conducted an experimental analysis of the activity of calcium in the calcium

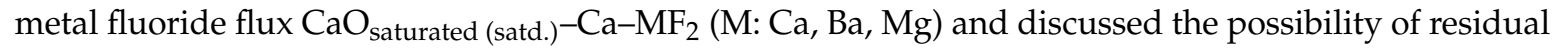
element removal by the flux. The results showed that the flux had excellent refining ability and a good tin removal effect in molten iron (as shown in Figure 4). 


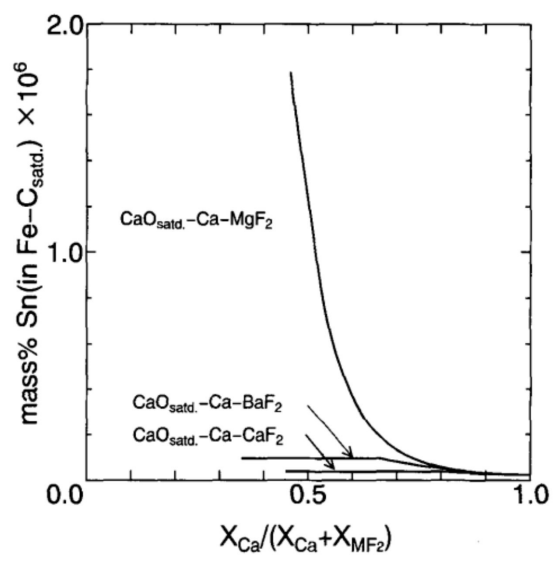

Figure 4. Balanced concentration of $\mathrm{Sn}$ in the carbon-saturated iron solution treated with calcium metal fluoride solvent [63].

Ghosh [64] used $\mathrm{Al}_{2} \mathrm{O}_{3}-\mathrm{Ca}_{\text {satd. }}-\mathrm{CaCl}_{2}$ slag to remove tin from molten iron at $1448-1648 \mathrm{~K}$ and indicated that the tin content in the molten iron decreased significantly with the decrease of initial tin content. In addition, tin removal from molten iron by $\mathrm{CaC}_{2}-\mathrm{CaF}_{2}$ was also studied at $1873 \mathrm{~K}$, but the effects of tin removal were not great.

By adding $\mathrm{CaC}_{2}$ into the molten steel, the residual elements $\mathrm{Sn}, \mathrm{Sb}$, and $\mathrm{As}$ can also be removed [65]. Experimental results showed that the rapid decomposition of $\mathrm{CaC}_{2}$ can accelerate the removal of residual elements under low initial carbon content and high-temperature conditions; in addition, the tin removal rate was also improved with increasing amounts of added $\mathrm{CaC}_{2}$ (as shown in Figure 5).

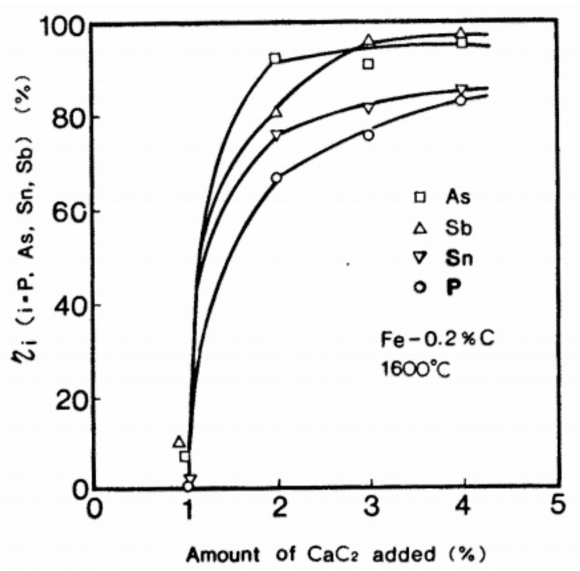

Figure 5. Relationship between residual element removal ratio and $\mathrm{CaC}_{2}$ addition [65].

The tin removal reaction using $\mathrm{CaC}_{2}$ can be divided into two steps: Firstly, $\mathrm{CaC}_{2}$ is decomposed into $\mathrm{Ca}$ at a high temperature, and then Ca reacts with the residual tin in the steel, as follows:

$$
2[\mathrm{Ca}]+[\mathrm{Sn}]=\left(\mathrm{Ca}_{2} \mathrm{Sn}\right)
$$

However, the recarburization phenomenon by $\mathrm{CaC}_{2}$ added into molten steel is more significant, and the carbon content of the molten steel, at the endpoint, is 40 times that of the initial carbon content. Therefore, the use of $\mathrm{CaC}_{2}$ to remove residual elements in the molten steel requires corresponding measures to prevent excessive carbon content in the final steel product.

In summary, calcium has a good removal effect on residual tin, but the application of $\mathrm{CaC}_{2}$ in industrial production still poses some serious problems; for instance, recarburization, high cost, and serious calcium loss. The calcium-containing slag system has a strong potential for tin removal, but the relevant reaction principles need further exploration and improvement. 


\subsection{Rare Earth Treatment}

Many metallurgists have conducted extensive research on the application of rare earth elements in steel since the 1960s. The early literature had reported that the addition of a small number of rare earth elements to steel can alleviate the effect of residual elements on the properties of steel. It can be found, from the rare earth-iron binary phase diagram, that rare earth elements can be mutually soluble with iron atoms in the molten iron [66], but their partition coefficient in the iron-based solid solution is extremely small, and most of the rare earth elements will preferentially accumulate at the defect area relative to the residual elements; for instance, the grain boundary. Thereby, the segregation of the residual elements at the grain boundaries can be suppressed or alleviated. Zhao et al. [67] explored the role of rare earth lanthanum in tin-ruthenium-bearing GCr15 steel and found that the damage of Sn to the thermoplasticity of the steel was reduced by suppressing the segregation of residual elements at the grain boundaries and refining the grains, but the reaction products of La and Sn were not found.

In addition, the rare earth can also directly react or undergo a solidification segregation reaction with the low-melting-point residual elements $\mathrm{Sn}, \mathrm{Sb}$, and so on, which are segregated at the grain boundary, and convert the residual elements into inclusions and fix them; thereafter reducing or eliminating the hazard of residual elements [68]. Yan et al. [69] and Wei et al. [70] studied the effects of the residual elements $\mathrm{Sn}$ and Sb on the impact toughness and the thermoplasticity of 34CrNi3Mo steel, and found that the composite phases $\mathrm{La}(\mathrm{Sn}, \mathrm{Sb})$ formed by lanthanum and the residual $\mathrm{Sn}$ and $\mathrm{Sb}$ were uniformly distributed on the appearance of an impact fracture and the properties of the steel were consequently improved. The fixing effects of lanthanum on residual tin in low-oxygen and low-sulfur steel were also demonstrated by Sha et al. [71]

Adding rare earth can effectively eliminate the effects of residual tin on the mechanical properties of steel: Yang [72] indicated that Ce will preferentially react with oxygen and sulfur in molten steel to form the compounds $\mathrm{Ce}_{2} \mathrm{O}_{3}$ and $\mathrm{Ce}_{2} \mathrm{O}_{2} \mathrm{~S}$ by blending high-purity rare earth lanthanum and high-purity metal tin in low-oxygen and low-sulfur industrial pure iron. When the oxygen content and sulfur content in the steel are reduced to a certain content, Ce begins to react with the residual element $\mathrm{Sn}$ to form a Ce-Sn compound. By comparing the standard Gibbs free energies between rare earth compounds at the steelmaking temperature [73] (as shown in Figure 6), it can be found that the rare earth would not react with residual elements directly, but primarily forms an oxide $(\mathrm{RE})_{2} \mathrm{O}_{3}$, and sequentially forms sulfur oxides $(\mathrm{RE})_{2} \mathrm{O}_{2} \mathrm{~S},(\mathrm{RE})_{\mathrm{x}} \mathrm{S}_{\mathrm{y}},(\mathrm{RE})_{\mathrm{S}}$, rare earth compounds $(\mathrm{RE})_{\mathrm{x}}(\mathrm{As}, \mathrm{Sn}, \mathrm{Sb})_{\mathrm{y}}$, residual elements (As, $\mathrm{Sn}, \mathrm{Sb}$, etc.), rare earth nitride $(\mathrm{RE}) \mathrm{N}$, and rare earth carbide $(\mathrm{Re}) \mathrm{C}_{2}$. Therefore, the rare earth reacts with the residual elements only when the oxygen and sulfur contents in the steel drop to an appropriate level.

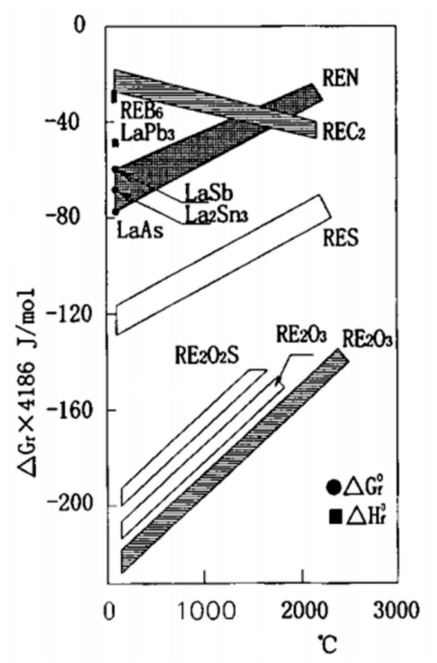

Figure 6. Relationship between the standard Gibbs free energy of formation and temperature of some rare earth compounds [73]. 
According to the above experimental studies, it can be found that, when the amount of rare earth added into the steel is low, the rare earth does not react with the residual element directly, as a certain amount of oxygen and sulfur are generally present in the molten steel. Furthermore, it is not reasonable to increase the amount of rare earth only for the purpose eliminating the influence of residual elements on the properties of the steel. Thus, it is necessary to discuss and study rare earth effects in many aspects.

\section{Summary}

With the depletion of high-quality iron ore resources and the increasing volume of recycled scrap steel, the accumulation of tin in steel is inevitable without effective removal of the residual tin. However, the current control processes for residual tin in steel are not satisfactory, and tin removal from steel cannot be achieved by conventional processes. Developing new types of tin removal agents and studying the reaction mechanisms of tin removal agents and slag systems to remove the residual tin in molten steel is likely a key work in the future. In addition, it is necessary to further explore the interaction between rare earth elements and tin, as well as the reaction mechanisms of rare earth in tin removal.

Author Contributions: Conceptualization, X.Z. and G.M.; Investigation and Resource Collection, X.Z. and M.L.; Writing —Original Draft Preparation, X.Z. and Z.L.; Writing—Review \& Editing, G.M.

Funding: This research was funded by The Youth Foundation of The State Key Laboratory of Refractories and Metallurgy, China [Grant No. 2018QN10].

Conflicts of Interest: The authors declare no conflict of interest.

\section{References}

1. Global Crude Steel Output Increases by $4.6 \%$ in 2018. Available online: http://www.webcitation.org/ 77nVyqbinp (accessed on 21 April 2019).

2. Ramadan, A.; Shash, A.Y.; El-Mahallawi, I.S.; Senk, D.; Mattar, T. Effect of Tempcore Processing on Mitigating Problems of Tramp Elements in Low C Steel Produced from Recycled Material. J. Iron. Steel Res. Int. 2015, 22, 582-589. [CrossRef]

3. Atkinson, M.; Kavanagh, L.; Mccutcheon, D.; Cox, P.S.; Shultz, R. Steel Industry Technology Roadmap; American Iron and Steel Institute: Washington, DC, USA, 2001; pp. 80-81.

4. Zhang, L. Influence of Residual Elements in Steel on the Quality of CSP Products. Met. Mater. Metall. Eng. 2009, 37, 12-15.

5. GB/T 700-2006. Carbon Structural Steel; Standards Press of China: Beijing, China, 2007.

6. ASTM A36/A36M-14. Standard Specification for Carbon Structural Steel; ASTM International: West Conshohocken, PA, USA, 2014.

7. Deng, S. The Influence of Residual Elements to Steel Quality and its Controlling. Liu Steel Technol. 2016, 2, $10-15$.

8. Zhang, M. Study on Plasticization Control of Oxide Inclusions in Tire Cord Steel. Steelmaking 2014, 30, 62-65, 78.

9. Li, L.; Zhu, R.; Guo, H.; Dong, J.; Li, F. Development of Non-leaded Free-Cutting Steel by Adding Tin. Int. J. Min. Met. Mater. 2003, 25, 312-314.

10. Reynolds, P.; Block, V.; Essel, I.; Klocke, F. Alternatives to Lead as a Machinability Enhancer in Free Cutting Steels. Steel Res. Int. 2007, 78, 908-914. [CrossRef]

11. Chen, S.C.; Zhu, R.; Xue, L.Q.; Lin, T.C.; Li, J.S.; Lin, Y. Effects of Elemental Sn on the Properties and Inclusions of the Free-cutting Steel. Int. J. Min. Met. Mater. 2015, 22, 141-148. [CrossRef]

12. Matsuoka, H.; Osawa, K.; Ono, M.; Ohmura, M. Influence of $\mathrm{Cu}$ and Sn on Hot Ductility of Steels with Various C Content. ISIJ Int. 1997, 37, 255-262. [CrossRef]

13. Nagasaki, C.; Kihara, J. Effect of Copper and Tin on Hot Ductility of Ultra-low and $0.2 \%$ Carbon Steels. ISIJ Int. 1997, 37, 523-530. [CrossRef]

14. Wang, Y.; Peng, D.Y. Effect of Residual Elements on Hot-workability of Stainless Steel. Spec. Steel 1990, 1, $24-29$. 
15. Wang, H. Harmful Effect of Sn Element on SUS304HC Austenite Stainless Steel. Iron Steel 2004, 39, 64-66.

16. Zhao, B.; Wang, J.; Du, Y.; Li, J. Effect of As, Sn and Sb on Temper Brittleness of 30CrMnSiA Steel. Trans. Mater. Heat Treat. 1995, 1, 13-17.

17. Zhou, S.; Guo, Y.; Shen, G. Control Critical Range of P and Sn of Cr-Mo-V Series Gun steel. Ordnance Mater. Sci. Eng. 1998, 1, 13-19.

18. Gulyaev, A.P.; Taran, A.V. Effect of Purity on the Temper Brittleness of Improved Structural Steels. Met. Sci. Heat Treat. 1971, 13, 844-848. [CrossRef]

19. Ding, Z.; Yan, Y.; Wang, S. Investigation on Reversible Temper Embrittlement and the Mechanism of Structional Steel. J. Dalian Railw. Inst. 1998, 19, 68-73.

20. Liu, F. Surface Enrichment of Residual Elements and Oxidation of the Austenite Grain Boundaries. Acta Metall. Sin. 1978, 14, 310-315.

21. Stephenson, E.T. Effect of Recycling on Residuals, Processing, and Properties of Carbon and Low-alloy Steels. Metall. Mater. Trans. A 1983, 14, 343-353. [CrossRef]

22. $\mathrm{Su}, \mathrm{Z}$.J. Research on the Behavior of Tin Removal from Tin-Bearing Iron Ores by Reduction Roasting. Master's Thesis, Central South University, Changsha, China, 2014.

23. Li, L. Development status and future demand outlook of ferroalloy industry in China. China Steel Focus 2013, 5, 15-24.

24. Guo, D.; Chu, S. Influence of Manganese Ferroalloys on Iron \& Steel Industry and its Purification of China. Ferro Alloy 2012, 43, 9-12.

25. Savov, L.; Volkova, E.; Janke, D. Copper and Tin in Steel Scrap Recycling. RMZ Mater. Geoenviron. 2003, 50, 627-640.

26. Noro, K.; Takeuchi, M.; Mizukami, Y. Necessity of Scrap Reclamation Technologies and Present Conditions of Technical Development. ISIJ Int. 1997, 37, 198-206. [CrossRef]

27. Zhang, X.; Ma, G.; Liu, M. Micro-segregation Model Calculation of Residual Tin in Boiler and Pressure Vessel Steel. Philos. Mag. 2019, 99, 1041-1056. [CrossRef]

28. Seah, M.P.; Hondros, E.D. Grain Boundary Segregation. Proc. R. Soc. Lond. 1973, 335, 191-212. [CrossRef]

29. Wu, P.; He, X. Grain Boundary Non-equilibrium Segregation: Retrospect/Prospect. Acta Metall. Sin. 1999, 35, 1009-1020.

30. Nachtrab, W.T.; Chou, Y.T. Grain Boundary Segregation of Copper, Tin and Antimony in C-Mn Steels at $900{ }^{\circ}$ C. J. Mater. Sci. 1984, 19, 2136-2144. [CrossRef]

31. Wang, M.Q.; Wang, K.; Deng, Q. Non-equilibrium Grain Boundary Co-segregation of Nickel and Tin in $2 \cdot 6$ NiCrMoV Steel. Mater. Sci. Technol. 2009, 25, 1238-1242. [CrossRef]

32. Sarafianos, N. Influence of the Combined Effect of Grain Size and Tin Grain Boundary Segregation on the Ductility of Carbon Steel During Hot-rolling. J. Mater. Sci. Lett. 1993, 12, 1522-1525.

33. Yuan, Z.X.; Jia, J.; Guo, A.M.; Shen, D.D.; Song, S.H. Cooling-induced Tin Segregation to Grain Boundaries in a Low-carbon Steel. Scr. Mater. 2003, 48, 203-206. [CrossRef]

34. Jia, J. Tin Segregation Behavior to Grain-boundary and the Hot Ductility of Low Carbon Steel. Master' Thesis, Wuhan University of Science and Technology, Wuhan, China, 2003.

35. Melford, D.A. Surface Hot Shortness in Mild Steel-study of Influence of Residual Elements with Aid of Electron Probe Microanalyser. J. Iron Steel Inst. 1962, 200, 290-299.

36. Geng, M.; Wang, X.; Zhang, J.; Wang, W.; Xiao, J. Enrichment of Residual Elements in Continuously Cast Slabs and Medium Plates. J. Univ. Sci. Technol. Beijing 2009, 31, 300-305.

37. Webler, B.A.; Sridhar, S. The Effect of Silicon on the High Temperature Oxidation Behavior of Low-carbon Steels Containing the Residual Elements Copper and Nickel. ISIJ Int. 2007, 45, 1245-1254. [CrossRef]

38. Suzuki, H.G. Strain Rate Dependence of Cu Embrittlement in Steels. ISIJ Int. 1997, 37, 250-254. [CrossRef]

39. Han, G.; Zhang, Y.; Jiang, T.; Huang, Y.; Li, G. Study on Preparation of Pellets for Iron-making from Tin, Zinc-bearing Iron Concentrates by Grate-kiln Process. Iron Steel 2009, 44, 8-13.

40. Zhang, Y.B.; Jiang, T.; Li, G.H.; Huang, Z.C.; Guo, Y.F. Tin and Zinc Separation from Tin, Zinc Bearing Complex Iron Ores by Selective Reduction Process. Ironmak. Steelmak. 2013, 38, 613-619. [CrossRef]

41. Zhang, Y.B.; Li, G.H.; Jiang, T.; Guo, Y.F.; Huang, Z.C. Reduction Behavior of Tin-bearing Iron Concentrate Pellets using Diverse Coals as Reducers. Int. J. Miner. Process. 2012, 110, 109-116. [CrossRef]

42. Fu, Z. Volatile Process of Tin in Reduction Roasting. Nonferr. Met. (Extr. Metall.) 1980, 1, 25-29. 
43. Wang, Z.W.; Wang, C.Y.; Lu, H.M. Investigation on Removal of Tin from Sn-bearing Iron Concentrates by Reduction Roasting. Min. Metall. 2005, 14, 63-66.

44. Yunnan Tin Company; Tin Metallurgy Editing Group of Kunming University of Science and Technology. Tin Metallurgy; Metallurgical Industry Press: Beijing, China, 1977; p. 11.

45. Kékesi, T.; Török, T.I.; Kabelik, G. Extraction of Tin from Scrap by Chemical and Electrochemical Methods in Alkaline Media. Hydrometallurgy 2000, 55, 213-222. [CrossRef]

46. Wang, H.B. DRI as a Substitute of Scrap Used for Steelmaking in Electric Arc Furnaces. Res. Iron Steel 2004, 32, 53-57, 61.

47. Wang, P. Popularization and Application of Hot Briquetted Iron (HBI). Iron Steel Scrap China 2005, 11, 11-18.

48. Zheng, H.Y.; Jiang, M.F.; Wang, G.H.; Hui, Y.A. Fe 3 C-a New Raw Material for Steelmaking. J. Iron Steel Res. 1996, 11, 60-63.

49. Gu, W.B.; Liu, X.; Yang, B.C. Clean Steel Making in the EAF at Baosteel. Iron Steel 2000, 35, 16-18, 38.

50. Li, S.Q.; Li, S.Q.; Wang, Y.N. Analysis and Study of Controlling Harmful Residuals in Molten Steel. Iron Steel 2001, 36, 70-72, 76.

51. Sun, G.L. Fundamentals on Precipitation Behavior of Residual Elements Tin and Antimony in Steel. Ph.D. Thesis, University of Science and Technology Beijing, Beijing, China, 2016.

52. Xu, K.D.; Jiang, G.C.; Hong, X.; Zheng, S.B.; Xu, J.L. Discussion on New Process Making Clean-steel from Scrap. Acta Metall. Sin. 2001, 37, 395-399.

53. Xiong, Y.L.; Yang, B.; Xiong, H.; Xu, B.Q.; Liu, D.C.; Dai, Y.N. Separation of Sn-Fe Alloys by Vacuum Distillation. Chin. J. Vac. Sci. Technol. 2012, 32, 820-824.

54. Lipart, J.; Łabaj, J.; Słowikowski, M.; Jama, D. Effects of Pressure on the Rate of Tin Evaporation from Liquid Iron. Arch. Metall. Mater. 2014, 59, 825-828. [CrossRef]

55. Savov, L.; Janke, D. Evaporation of $\mathrm{Cu}$ and Sn from Induction-stirred Iron-based Melts Treated at Reduced Pressure. ISIJ Int. 2000, 40, 95-104. [CrossRef]

56. Savoa, L.; Tu, S.; Janke, D. Methods of Increasing the Rate of Tin Evaporation From Iron-based Melts. ISIJ Int. 2000, 40, 654-663. [CrossRef]

57. Matsuo, T.; Maya, K.; Nishi, T.; Shinme, K.; Ueno, A.; Anezaki, S. Removal of Copper and Tin in Molten Iron with Decarburization under Reduced Pressure. ISIJ Int. 1996, 36, s62-s65. [CrossRef]

58. Nishi, T.; Fukagawa, S.; Shinme, K.; Mastuo, T. Removal of Copper and Tin in Molten Iron with Combination of Plasma Heating and Powder Blowing Decarburization under Reduced Pressure. ISIJ Int. 1999, 39, 905-912. [CrossRef]

59. Sasaki, N.; Uchida, Y.I.; Miki, Y.J.; Matsuno, H. Fundamental Study of Sn Removal from Hot Metal by $\mathrm{NH}_{3}$ Gas Blowing. ISIJ Int. 2014, 54, 1807-1812. [CrossRef]

60. Matsuo, T. Removal of Copper and Tin in the Molten Steel with Plasma Flame. Tetsu Hagané 1989, 75, 82-88. [CrossRef]

61. Zaitsev, A.I.; Zaitseva, N.E.; Shakhpazov, E.K.; Mogutnov, B.M. Potentialities of Simultaneous Removal of Tin and Copper from Molten Iron through Evaporation. ISIJ Int. 2004, 44, 957-964. [CrossRef]

62. Tsukihashi, F. Physical Chemistry of Removal of Tramp Elements from Steel. In Proceedings of the 9th China-Japan Symposium on Science and Technology of Iron and Steel, Xian, China, 8-9 November 2001; pp. 59-66.

63. Ochifuji, Y.; Tsukihashi, F.; Sano, N. The Activity of Calcium in Calcium-metal-fluoride Fluxes. Metall. Mater. Trans. B 1995, 26, 789-794. [CrossRef]

64. Ghosh, D. Removal of Tin and Copper from Liquid Iron by $\mathrm{Al}_{2} \mathrm{O}_{3}$-Saturated Ca-CaCl $\mathrm{Clags}_{2}$ at 1448 to 1648 K. Metall. Mater. Trans. B 2009, 40, 508. [CrossRef]

65. Kitamura, K.; Takenouchi, T.; Iwanami, Y. Removal of Impurities from Molten Steel by CaC2. Tetsu Hagané 1985, 71, 220-227. [CrossRef]

66. Zhang, F.Z.; Gu, L.J. Rare Earth-iron Binary Phase Diagrams. Chin. Rare Earths 1981, 1, $72-85$.

67. Zhao, Y.B.; Wang, F.M.; Li, C.R.; Xiao, J.G. Effect of Lanthanum on GCr15 Bearing Steel with Tin and Antimony. J. Chin. Rare Earth Soc. 2007, 25, 229-233.

68. Wilson, W.G.; Kay, D.A.R.; Vahed, A. The Use of Thermodynamics and Phase Equilibria to Predict the Behavior of the Rare Earth Elements in Steel. JOM 1974, 26, 14-23. [CrossRef]

69. Yan, C.L.; Wang, F.M.; Wei, L.J.; Fu, Q.; Wu, C.J. Improvement of Lanthanum on Impact Toughness of 34CrNi3Mo Steel Containing Sn, Sb Residual Elements. J. Univ. Sci. Technol. Beijing 2004, 26, 277-281. 
70. Wei, L.J.; Wang, F.M.; Xiang, C.X.; Zhang, X.; Liu, K.M.; Wu, C.J. Improvement of Lanthanum on Hot Ductility of 34CrNi3Mo Steel Containing Residuals. J. Chin. Rare Earth Soc. 2003, 21, 311-314.

71. Sha, A.X.; Wang, F.M.; Wu, C.J.; Dong, L.R.; Li, S.Y.; Chen, Y.X.; Zhu, L.X. Fixation of Tramp Elements in Steel by Lanthanum. Chin. J. Rare Met. 2000, 24, 287-291.

72. Yang, Z.L. Research on the Interaction Rule between the Rare Earth Cerium and the Low Melting Point Metallic Tin in the Steel. Master's Thesis, Guizhou University, Guiyang, China, 2006.

73. Yu, J.S.; Yu, Z.S.; Zhang, F.Z. Handbook for Rare Earth Treated Steels; Metallurgical Industry Press: Beijing, China, 1993; p. 22.

(C) 2019 by the authors. Licensee MDPI, Basel, Switzerland. This article is an open access article distributed under the terms and conditions of the Creative Commons Attribution (CC BY) license (http://creativecommons.org/licenses/by/4.0/). 